\title{
EARLY TREATMENT OF ACUTE MYOCARDIAL INFARCTION AND ITS REGIONAL DIFFERENCES IN BÉKÉS COUNTY
}

\author{
AZ AKUT MIOKARDIÁLIS INFARKTUS KORAI ELLÁTÁSA ÉS \\ ANNAK TERÜLETI KÜLÖNBSÉGEI BÉKÉS MEGYÉBEN
}

\begin{abstract}
Szilvia BEKE ${ }^{\mathrm{a}}$
${ }^{a}$ Gál Ferenc College Faculty of Health and Social Sciences, Institute of Health Sciences 5700 Gyula, Szent István u. 17-19, mobile: +36 309034945 , email: beke.szilvia@ gff-gyula.hu
\end{abstract}

Cite this article: Beke, S. (2019). Early Treatment of Acute Myocardial Infarction and its Regional Differences in Békés County. Deturope, 11(1), 182-195.

\begin{abstract}
Similarly to Western Europe, our country is also fighting against cardiovascular diseases. The fight is strongly influenced by the prevention and early treatment of the evolved disease which define overall chance of survival of the patient beside life saving.

The study examines this early treatment with statistical analysis. The aim is to form a comprehensive image of the current situation of Békés County of Hungary focusing on both the cardiovascular diseases (such as infarction) and the field of pre-hospital and hospital care. During my research I have leant on secondary data analyses relying on the data given by the National Ambulance Service in Békés County and the Invasive Cardiology Department of Békés County Central Hospital's Pándy Kálmán Member Hospital. In view of modern treatment, Békés County has a situation to be examined as both the pre-hospital and hospital treatments have been improved in the last period. Two new ambulance stations were opened in the county, moreover, since 2013, an invasive cardiology unit has been operating in the Békés County Central Hospital’s Pándy Kálmán Member Hospital.

As the result of the research, we can state that the investments of the previous period have promoted the decrease of health and accessibility inequalities, however, the data of mortality rate show that there is a need of further investments. At the same time, these investments have to deal with the complex procedure from the appearance of the symptoms to the treatment.
\end{abstract}

Keywords: healthcare treatment, availability, accessibility, acute myocardial infarction (AMI), regional inequalities

\begin{abstract}
Absztrakt
Nyugat-Európához hasonlóan hazánk is jelentős küzdelmet folytat a kardiovaszkuláris megbetegedésekkel. A küzdelmet a prevención túl számottevően befolyásolja a már kialakult megbetegedés korai ellátása, mely a konkrét életmentésen túl az egyén további életesélyeit is meghatározza.

A tanulmány ezt a korai ellátást vizsgálja statisztikai elemzéssel, a cél átfogó kép kialakítása Békés megye jelenlegi helyzetéről, mind a szív- és érrendszeri megbetegedések (föként infarktus), mind pedig a prehospitális, illetve hospitális ellátás területén. Kutatásom során elsősorban másodlagos adatelemzésre, az Országos Mentőszolgálat Békés megyei kirendeltségének, valamint a Békés Megyei Központi Kórház Pándy Kálmán Tagkórház Invazív Kardiológiai Osztályának adataira támaszkodom.

A korszerủ ellátás tekintetében Békés megyének több szempontból vizsgálatra érdemes helyzete van, az elmúlt időszakban mind a prehospitális mind pedig a hospitális ellátás területén fejlődést figyelhetünk meg. Két új mentőállomás került átadásra a megyében, 2013 óta pedig a Békés Megyei Központi Kórház Pándy Kálmán tagkórházában is müködik invazív kardiológiai részleg.

A kutatás eredményeként elmondható, hogy az elmúlt időszak fejlesztései elősegítették az egészség-, és a hozzáférési egyenlőtlenségek csökkentését, azonban a halálozási adatok azt mutatják, hogy további
\end{abstract}


Beke, S.

fejlesztésekre van szükség. Ugyanakkor a fejlesztéseknek a komplex folyamatot kell átfogniuk a tünetek jelentkezésétől a gondozásig.

Kulcsszavak: egészségügyi ellátás, elérhetőség, hozzáférhetőség, akut miokardiális infarktus (AMI), területi egyenlötlenség

\section{INTRODUCTION}

Epidemiological or health transition means a replacement of infectious diseases by chronic diseases over time due to increased life expectancy as a result of improved health care and disease prevention (Porta, 2014). This transition has been occurred in more developed countries from the middle of the $20^{\text {th }}$ century. The most important health consequences of health transition are based on civilization harms and lifestyle risk in the most developed countries (e.g. unhealthy nutrition, stress, sedentary lifestyle, addictions etc.). These harms and risks have resulted increasing number and rate of non-communicable diseases (chronic non-infectious diseases). These diseases are especially cardiovascular diseases, tumors, chronic diseases of respiratory and digestive system. They can be traced back to high blood pressure, high level of cholesterol, obesity, health effects of smoking etc. (OECD, 2018). The previous decades basically were about the fight against chronic non infectious diseases (non-communicable diseases) both in Hungary and the developed Western European countries. The biggest challenge is the cardiovascular mortality, as it is responsible for more than 50 per cent of all death (Kaszás et al., 2012, WHO, 2018).

Among cardiovascular diseases one of determinative death causes is so called Acute Myocardial Infarction (AMI is briefly) which can give comprehensive information about survival chances and access to health care according to different phases of infarction treatment (Maxwell, 1999). Early treatment - which is one of the most important phase of infarction treatment - has equal or more importance in the improvement of the health status than prevention, and early treatment determines the survival rates significantly beside life saving. Early treatment contains pre-hospital treatment (e.g. ambulance care) as well as emergency care which is the part of in-hospital treatment. In this study I intend to show early treatment in two sections which are in interaction, built upon one another, but there are marginal differences. The first section is the so-called pre-hospital treatment in which the early arrival of the ambulance and the provision of the professional treatment is significant. The other section is the hospital treatment where the emergency units and invasive cardiology units have important roles due to the Percutaneous Coronaria Intervention (PCI) which is the modern medical care of AMI (Best, 2011). 
The paper also discovers regional inequalities regarding early treatment of AMI within Békés County. These inequalities can show us the primary possibilities and barriers to access to early treatment. The medical status of a region is extremely significant as it is not only in a strong relationship/connection with the inhabitants' living standards, but the economic development of the area, as well. Better medical status means higher productivity and wider pool of employees (Egri, 2017, Egri, Tánczós, 2015). Notwithstanding this, modern societies have to face a number of health and healthcare issues, recently. This is the main cause that there are many approaches which are examining the connection between health inequalities and regional inequalities. Moreover, health inequalities not only imply social or spatial inequalities, but also socio-spatial inequalities as a whole (Black et al., 1985, Jones, Moon, 1987). It is also important to recognize that health inequalities have spatial aspects that reflect the social context of health inequalities. In Hungary, many authors have already addressed this issue particularly at county level (e.g. Kiss, 2016, Uzzoli, 2016 etc.). Some other Hungarian authors prefer using local case study at micro-regional level to examine spatial aspects of health inequalities (e.g. Vitrai, 2011, Pál, 2017 etc.). Among primary results of these researches we have to mention that many authors could point out the disadvantaged health position of Békés County in comparison with the national averages according to the main health indicators (e.g. life expectancy, cause and age specific mortality rate etc.).

\section{OBJECTIVES AND METHODS}

Our project is aimed to analyze the connection between health inequalities and access to health care through its regional inequalities. To identify the role of accessibility in regional disparities of health inequalities we use a case study. In this case study we define health inequality with morbidity and mortality data of Acute Myocardial Infarction (AMI), while we can examine the possibilities and barriers in access to infarction care (cardiological care). The spatial framework of this statistical examination is based on national, county (NUTS-3) and micro-regional level (LAU-1).

This article intends to give a comprehensive image of the current health situation of Békés County focusing on cardiovascular diseases such as Acute Myocardial Infarction, and its prehospital and hospital treatment. I have used secondary data analysis relying on the data given by the National Ambulance Service in Békés County, the Cardiology Department of Békés County Central Hospital's Pándy Kálmán Member Hospital. All statistical data is suitable to analyze current situation and temporal changes in Békés County between 2000 and 2017. 
The following data were used in statistical analysis: number of ambulance and ambulance stations and its territorial coverage, type of rescue team, number of Coronarography cases etc. The basic reason to use them was to describe infrastructural conditions of early treatment and to discover their regional differences within Békés County. Furthermore, some computations also have been done in order to answer the questions see below. For example, cause-specific death rate was calculated or ambulance stations were categorized according to its type of rescue team etc. However, some difficulties also were encountered during the data collection, because basically there are three main types of ambulance care (primary ambulance, ambulance transport, guarded patient transport). After 2008 the ambulance task of guarded patient transport was separated from official ambulance tasks (primary ambulance, ambulance transport) from the National Ambulance Service in Békés County. So, all data before 2008 were cleared by the cases of guarded patient transport. It means all used data were based on cases of primary ambulance, ambulance transport.

To study features of early treatment of AMI is important to define PCI as a modern cardiology intervention. Percutaneous coronary intervention (PCI) is a non-surgical procedure used to treat narrowing (stenosis) of the coronary arteries of the heart found in coronary artery disease.

The questions to be answered during this study are the following:

- How can we describe the situation of Békés County according to the health state?

- What regional inequalities can be seen in the AMI treatment of Békés County?

- How can we describe the availability of AMI during early treatment?

- What is the size and direction of the progress experienced in the last 5 years focusing on AMI in early treatment in order to reduce regional inequalities?

Besides statistical analysis I also applied other examination techniques as the part of desk research to answer these questions. Thus, I prepared literature review as well as documentanalysis. In this later case, I could analyze the most important strategies and other local policy documents realized in Békés County. All results and experiences of this paper can be use to make some proposals for decision-making.

All results of statistical analysis as well as all experiences of desk research can draw attention to paradox health situation of Békés County. 
Beke, S.

\section{RESULTS}

The health state of a county is significantly determined by its demographic situation, and the same is observed in Békés County, as this county is the most aging one in Hungary, which is influenced by the rising rate of the non-communicable diseases. In Békés County the rate of inhabitants over 65 years is 19.4 per cent, while the number of inhabitants under 14 is 13.3 per cent. That is why the data of mortality in Békés County is higher than in any other counties, as its figure was 15.9 per cent in 2015 , while the national figure was 13.4 per cent per one thousand inhabitants (Beke, 2017). The reasons of mortality can be seen in Fig. 1 which presents that 55 per cent of mortality is due to cardiovascular diseases and nearly one third of that rate (28.9\%) is caused by ischemic cardiovascular diseases. AMI is a typical ischemic heart disease and it occurs when the heart's tiny arteries do not function normally.

Figure 1 Percentage rate of mortality according to the causes of death in Békés County

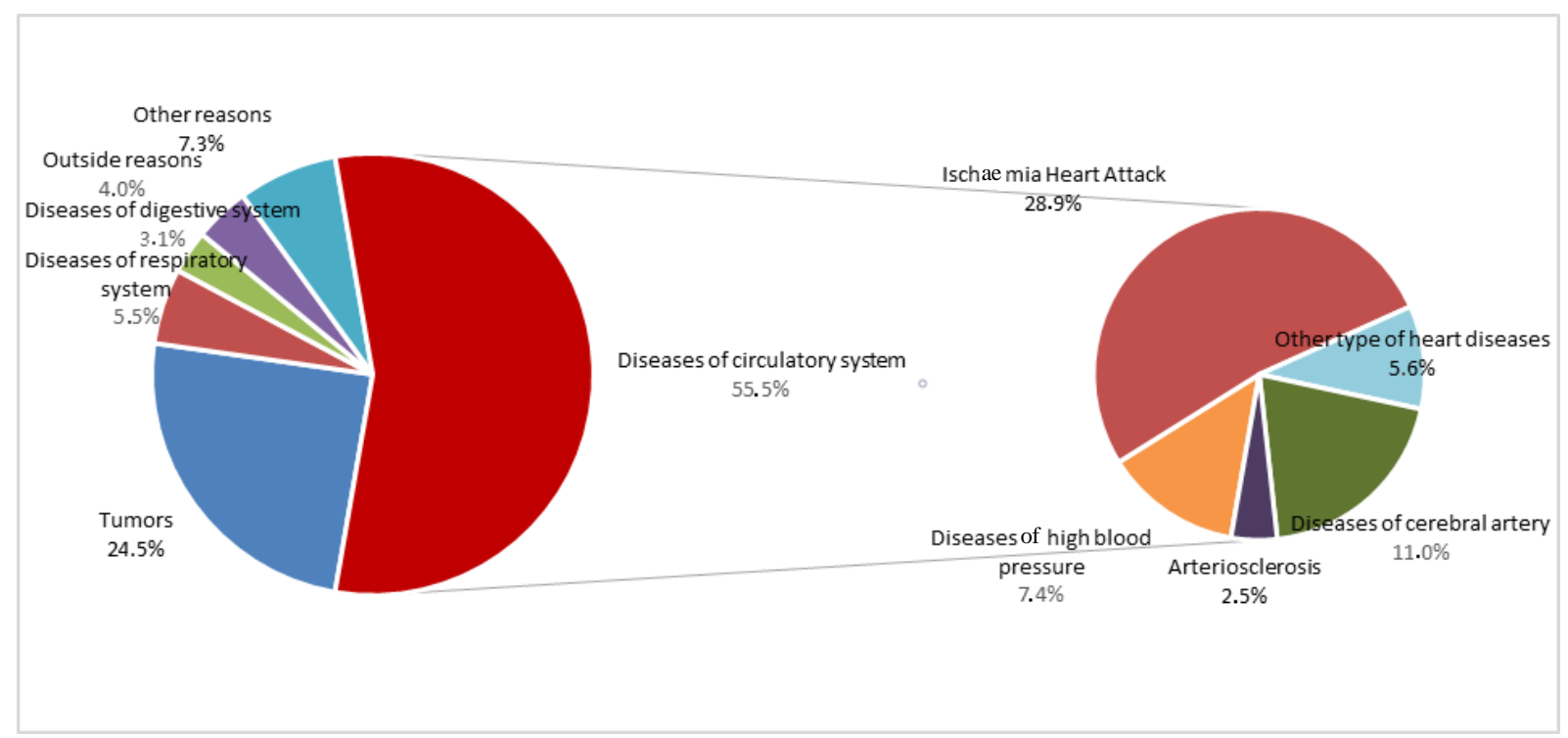

Source: Statistic Annals of Békés County, 2015

The improvement of mortality rates can be achieved partly by using prevention and emphasizing healthy lead of lifestyle, and partly by the development of treatment and the use of PCI in early period. However, the way which led to the improvement of the treatment in cardiology and the reduction of regional inequalities of healthcare due to infrastructural development has been long.

The specialized treatment of cardiologic diseases has been introduced half a century ago, as the first coronary intensive units were established, where the methods of intensive patient observing and treating were introduced. It was followed by the use of thrombolysis, where 
Beke, S.

timing got a significant role in treatment. Introducing medicine like thrombocyta aggregation impeding medicine and statins decreasing cholesterol level together with secondary prevention meant a great development in the frame of treatment (Kiss et al., 2014).

The appearance of telemedicine in the field of treatment and the use of TTECG machines which are found in ambulance at every level shows another step forward and they have become a process targeting the reduction of time (Bán, 2017a, 2017b). Nowadays, the most modern method of treatment is the revascularization, which plays an important role not only in rescuing the patient's life, but it affects the further living standards, as well. At the same time, timing determines the effectiveness of treatment and its possibilities (Rácz et al., 2010). That is why opening the invasive cardiology department in the county in 2013 was significant, because before that, patients suffering these problems were taken to another hospital almost $100 \mathrm{kms}$ away (Szeged, Debrecen).

Many factors influence the early treatment besides the existing capacities, and they are important participants of this period, such as the experts on duty, the paramedics, the ER workers and, last but not least, the patient itself, because the time of hesitation negatively affects the experts. When a patient with ST-elevation acute myocardial ${ }^{6}$ infarction cannot be taken directly to PCI laboratory, instead, (s)he is taken to the ER by an acquaintance, the mortality can be risen by 20 per cent (Kiss et al., 2014).

Observing the regional treatment, this study is not suitable to describe the above mentioned last factor, because it is defined by many subjective factors felt and experienced by the patient. On the other hand, the regional inequalities of the objective treatment factors are important to study. Fig. 2 shows the ambulance stations in Békés County and their areas covered. At microregional level Békés County is evenly covered by ambulance stations. Many of them are relative smaller ones but they can provide ambulance care spatially balanced. Ambulance stations in Békéscsaba and Orosháza cover the largest area within the county.

\footnotetext{
${ }^{6}$ On the EKG line P, Q, R, S, T waves are separated and the abnormal changes in this line is the ST elevation which are called STEMI, while the heart attack without it is called non-STEMI (NSTEMI)
} 
Figure 2 Working territories of the ambulance stations in Békés County, 2018

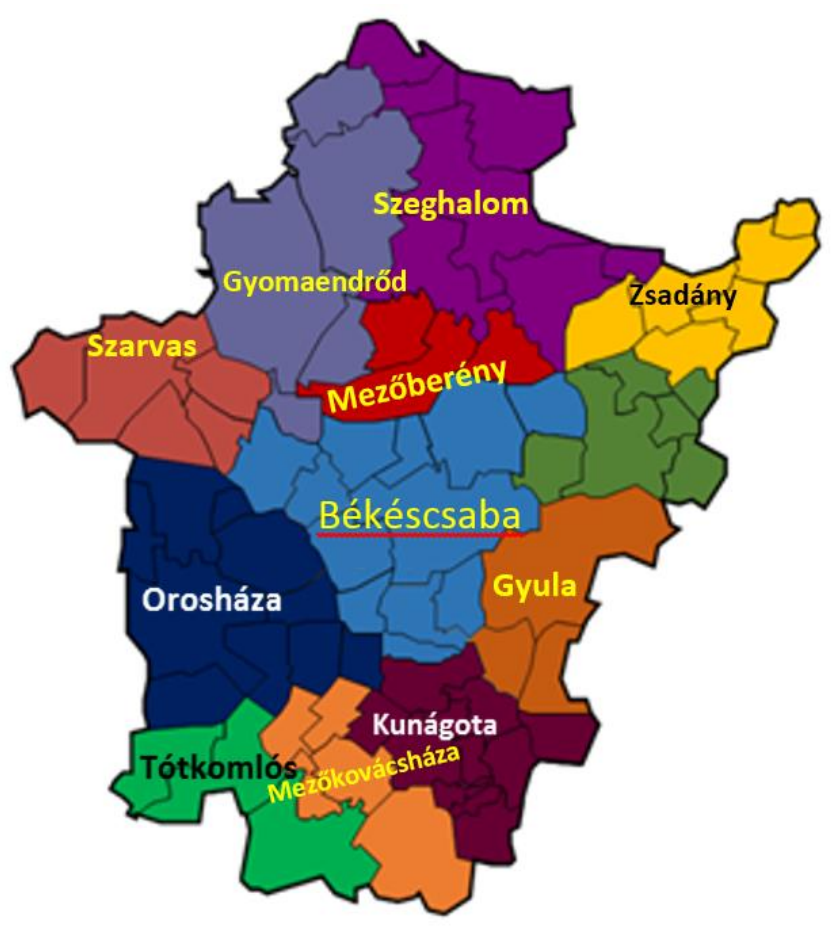

Source: Author's elaboration using the data of the National Ambulance Services' Branch Office in Békés County 2018.

Two ambulance stations were opened in Mezőberény and Tótkomlós in 2015 (Fig. 2), before that time, these two areas were operated by the stations of Orosháza and Békéscsaba (MTI, 2017). There are not any ambulances in the stations of these settlements but TTECG can be found in the ambulance which can send the signs using radio waves to the ER of Gyula, therefore, the regional inequality has been greatly reduced. The most important aspect of the TTECG sign receiver units was that they have to be near to PCI centres in order to act fast (Bán, 2015). The accessibility inequalities were decreased more as a rescue point operates at the highlighted spot. Currently, there is only one in the county in Dévaványa. Because of the longer arrival time of the ambulance, there is a permanent ambulance between 8 a.m. and 4 p.m. at the settlement.

The number of ambulances in operation is indicated in Fig. 3, according to which, there is a slight decrease, although it is due to the fact that the transfer of patients has been out of the tasks of the National Ambulance Services, and they deal with rescue tasks, exclusively. In 2000 there were altogether 48 ambulances in operation in Békés County, while in 2017 the number of them was only 38 . This slight decrease tendency has happened mainly during the 2000s. 
Beke, S.

Figure 3 The changes of the number of ambulances in operation in Békés County, 2000-2017
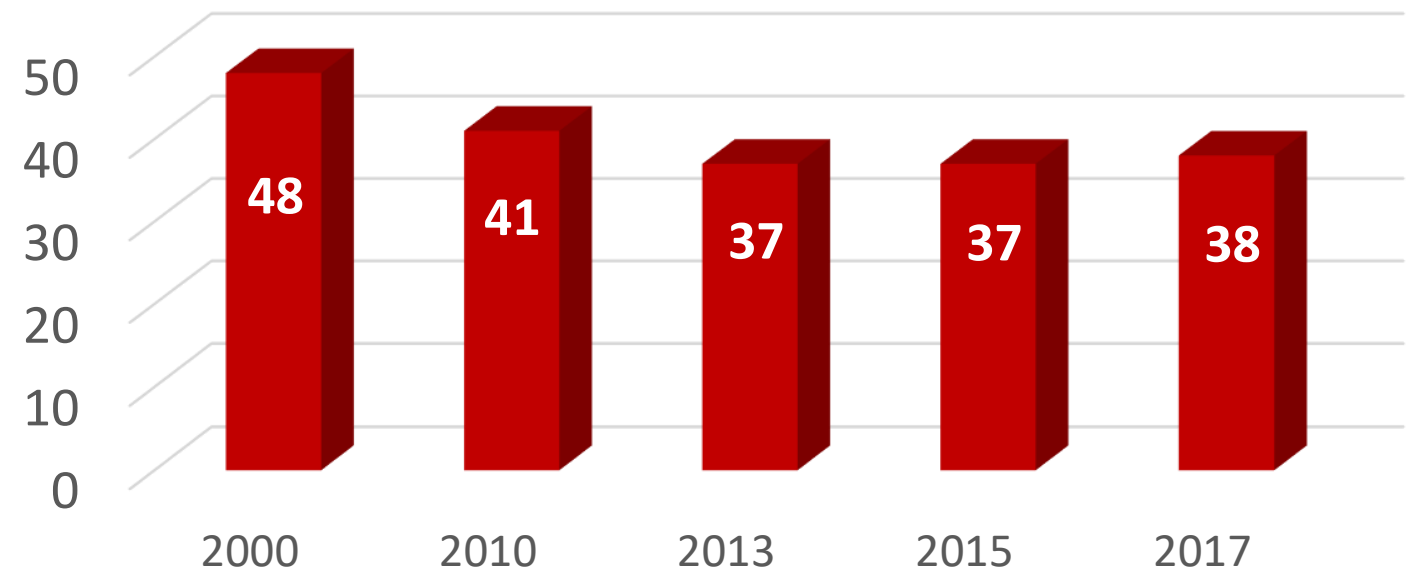

Source: Author's elaboration using the data of the National Ambulance Services' Branch Office in Békés County 2018.

In 2015, 748 ambulances operated and 170 paramedics worked. If we study its regional data, we can state that the county has a suitable provision compared to the national rate. Between 2010 and 2015, 23 new ambulance stations were opened across the country and 2 of them were in Békés County. In 2011, the average age of the ambulances was 8.9 years, while today, due to the investments, it has reduced to 6.9 years. Fig. 4 shows the ambulances and their quality of equipment. The largest ambulance station with its diverse rescue team can be found in Békéscsaba in the seat of Békés County. The smallest ambulance stations are standing in Kunágota, Mezőberény, Tótkomlós, Zsadány where there are not any medical rescue track or emergency car. The other ambulance stations in the county are middle-sized and have at least one emergency car.

Figure 4 Types of rescue teams in the county

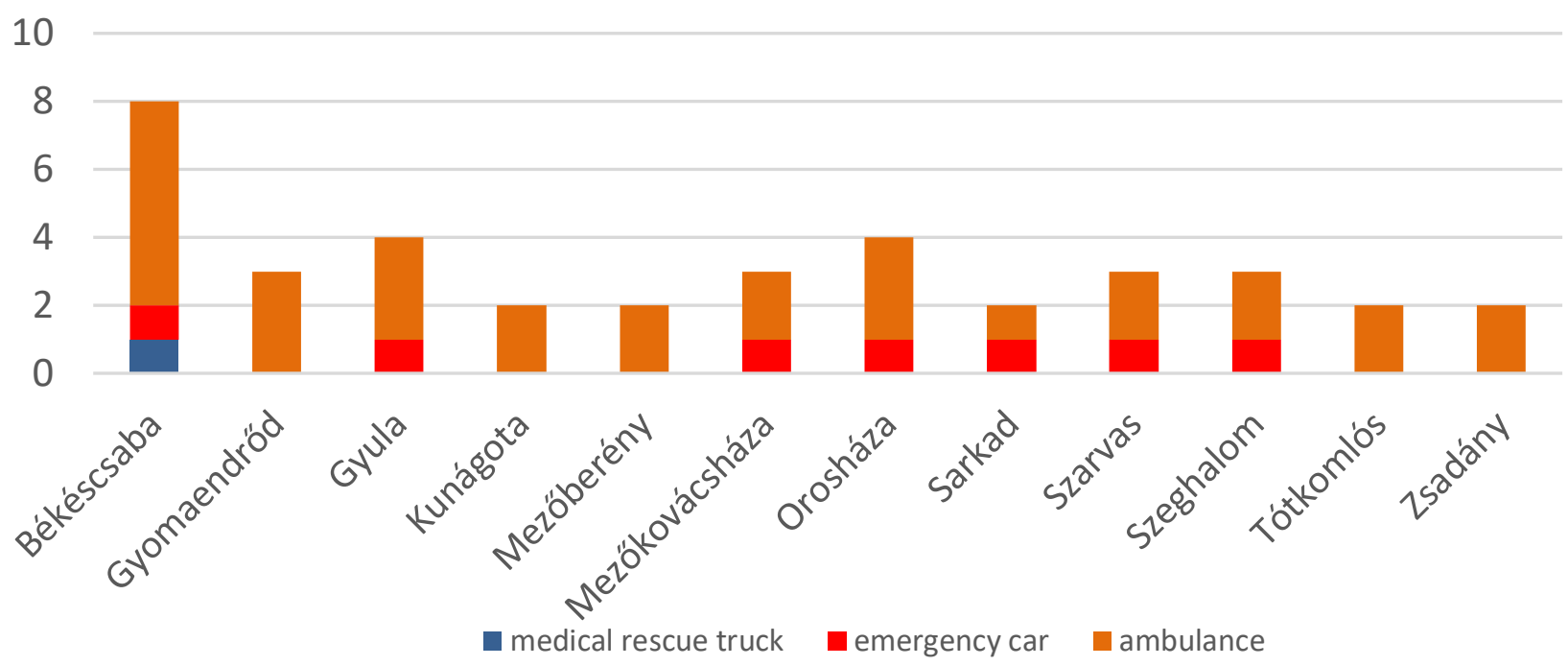

Source: Author's elaboration using the data of the National Ambulance Services' Branch Office in Békés County 2018. 
Beke, S.

By studying these data that focus on the regional aspect, one can observe that those settlements situated in the middle line of the county are well supplied, and when there are more cases demanding higher level of treatment simultaneously, they can be provided, while the provision of the southern regions is not sufficient (Fig. 5). The situation has become more difficult, as there are no rescue points in these areas. According to the leading ambulance officer, they constantly observe the cases, and as a result, they are thinking of Medgyesegyháza as a possible rescue point, although there have not been any negotiations on building one. The only one medical rescue truck is in the seat of Békés County (Békéscsaba).

Figure 5 Medical rescue truck or emergencies case works garages in Békés County, 2018.

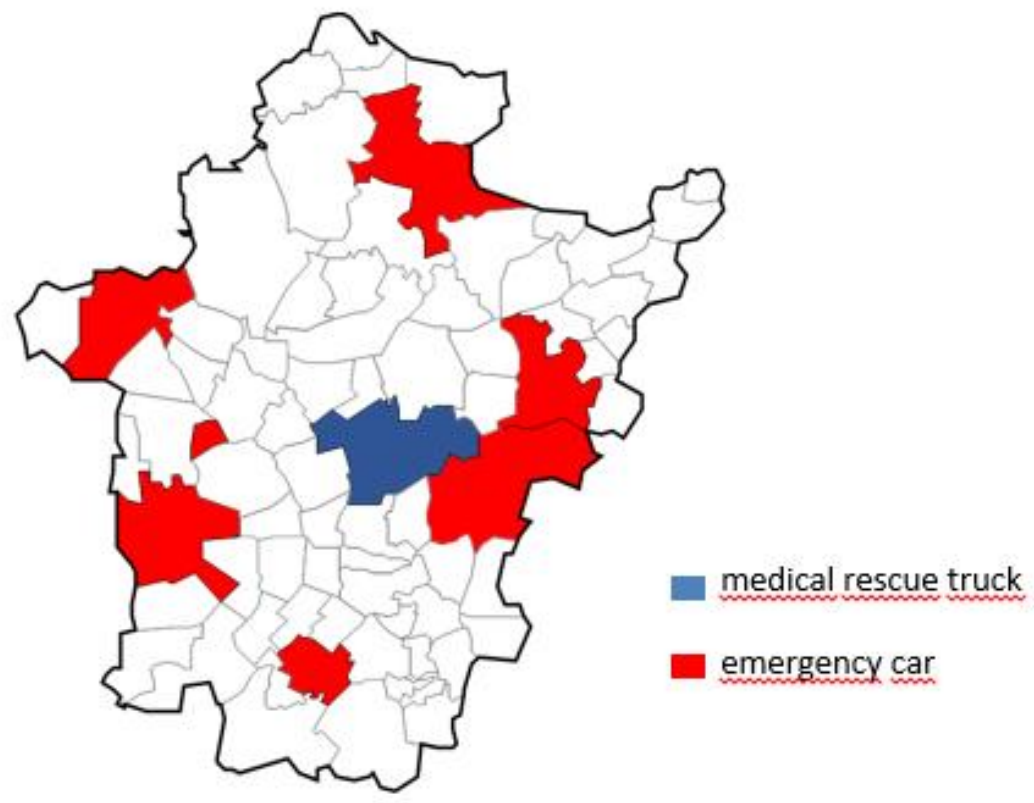

Source: Author's elaboration using the data of the National Ambulance Services' Branch Office in Békés County 2018.

These can be satisfied with the above mentioned use of TTECG, which provides the experts with the patient's ECG immediately, and after analysing it, they can decide how the patient could be treated later. In this case, more dilemmas can emerge, as when there is a so-called myocardial infarction with ST elevation, the decision is clear, but the case with these symptoms requires a treatment with different process. It is a fact that according to the data of the National Heart Attack Register, the surviving data of patients with both STEMI and NSTEMI are better if they have had revascularisation (Jánosi, Offner, 2015). That is why the quality of treatment and its possibilities determine the patients 1 further life for a long time.

Similar studies have been conducted at an international scale in 555 hospitals of about 20 countries, where patients with Acute Coronaria Syndrome were followed both in the short and 
Beke, S.

the long term. In these cases, the effectiveness of anticoagulant therapy was studied beyond revascularisation, which highlighted the significance of revascularisation (Annemans et al., 2016, Ertaş, Tokğözoğlu, 2016).

Focusing on the rescue data of Békés County, there was no possibility to tighten the data, especially to the calls of myocardial infarction. Nevertheless, it can be stated that annually there are 350 to 400 calls of the ambulance because of circulatory failure, and experts start resuscitation in 280 to 300 cases and their primer success is about 15 per cent, while the permanent success is only about 5 per cent (National Ambulance Service in Békés County, 2018).

According to the information given by the National Ambulance Service's Békés County Branch Office, they are able to provide the arrival time within 20 minutes to any settlement in the county. After arrival and the professional treatment on the spot, the next step is the revascularization as soon as possible, which is done by PCI laboratories. The PCI lab in Békés County was opened in 2013, which satisfied the need of cardiology, as before that, the patients were taken to Szeged, Debrecen or Szolnok, and that enlarged the timing significantly. Currently, the cardiology invasive unit operates in 24 hours, and it is provided that the time is no more than 20 minutes from the gate of the hospital to the operating table. Fig 6 shows increasing number of coronarography cases - such as AMI - supplied in PCI centre of Gyula. In 2013 there were approximately 700 cases while now there are almost 1600.

Figure 6 Coronarography cases of Békés County Central Hospital Pándy Kálmán Member Hospital since $1^{\text {st }}$ July 2013.

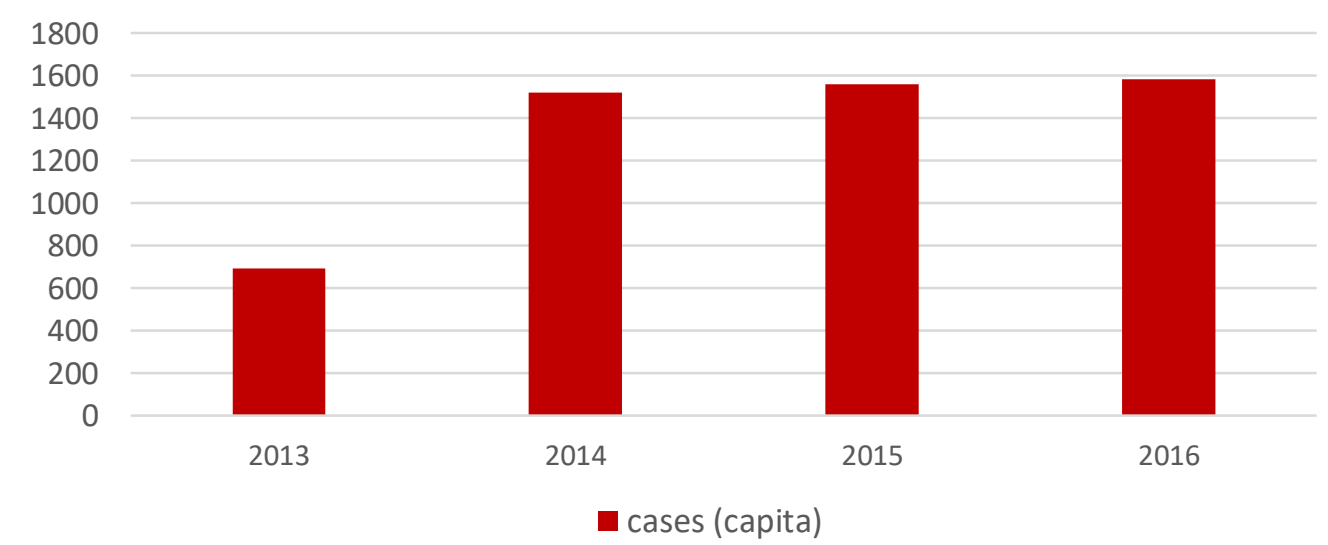

Source: Author's elaboration using the data of the BMMK Pándy Kálmán Member Hospital's PCI Laboratory 2013-2016.

As shown by the data, slightly over 1500 patients are treated here annually (Fig 6). There was a comparative study in 2013 elaborated by the colleagues of the cardiology department in 
Beke, S.

which they focused on primarily the changes of treatment and timing in the region. That study revealed the following observations:

- During a study elaborated in 1985-86, the time of making a decision means the time which elapses until the patient enters the healthcare from the appearance of symptoms, which took 3 hours and 25 minutes, but the same time period was 58 minutes in 2015. It partly refers to the better knowledge of the patients and their ability to recognise the symptoms.

- The time period entering to hospital was 12 hours, but is has reduced to an average of 2 hours and 23 minutes.

- There were not found any significant differences with respect to the time when heart attack appeared, as it happened in the early morning hours (Márk et al., 2015).

It should be emphasized that this comparative research studied the data between 2011 and 2013, which was before the opening of the PCI laboratory. Experts state that these positive changes are due to the patients' health awareness and the regular trainings in the general practitioner's system (GP), as well as the improvement of the organization of the ambulance system.

According to these findings there are numerous positive changes, but new questions have been raised:

- What changes at any levels of prevention will improve the current status further?

- How can be the time of hesitation further reduced?

- How far can be the telemedicine expanded in the field of treatment, rehabilitation and care?

- Where, how long and what forms do the colleagues have to ask for the urgent changes in order to enlarge the effectiveness? What is the region which needs urgent investment, improvement?

In general, in the last period there have been many positive changes in the AMI treatment with respect to providing the chances of availability of treatment, thus, more patients are given PCI in the county (Uzzoli et al., 2017). At the same time, it is only the beginning of the way on which we should not stop, but we have to step forward, thinking in a complex process from the appearance of the symptoms to the treatment. To summarize all results of this examination see above in this paper, I can emphasize the role of infrastructure developments in early treatment 
Beke, S.

in health care of AMI, because after opening a new PCI centre in Gyula AMI mortality data could begin to improve in Békés County.

\section{SUMMARY}

The study intended to show the current situation of Békés County focusing on pre-hospital and hospital treatment in connection with Acute Myocardial Infarction (heart attack). The current improvements have promoted the reduction of health and availability inequalities, although the mortality rates show that there is a need of further improvements. Developments have to influence the complex process from the appearance of symptoms to the process of treatment, which means the introduction of a comprehensive practice supported by specialized protocols. This study is not suitable to observe it, but the results clearly show the fact that the recent practice is only the first step towards providing a more effective treatment.

The primary results of this paper give more information about general conditions of health care regarding infarction. These results can confirm that infrastructural developments in early treatment in Békés County (new PCI-centre or new ambulance stations) can increase survival chances after infarction. The consequence is to emphasize the determinative role of early treatment in the entire health care which improves the conditions of accessibility. The other important result is marked improving tendency has happened in early treatment infarction care of Békés county in the latest years which went together with stronger cooperation between prehospital and hospital care of infarction as the part of early treatment. Based on these results and consequences the proposal for decision-making is that integrated health care can strengthen the possibilities of accessibility.

The further step in our research project is to evaluate the characteristics of hospital care regarding infarction based on making semi-structured interviews made with medical professionals and patients, too.

\section{Acknowledgement}

The study is based on research project no. K 119574 which has been implemented with the support provided from the National Research, Development and Innovation Fund of Hungary.

\section{REFERENCES}

Annemans, L., Danchin, N., Van de Werf, F., Pocock, S., Licour, M., Medina, J., Bueno, H. (2016). Prehospital and in-hospital use of healthcare resources in patients surviving, acute coronary syndromes: an analysis of the EPICOR registry. BMJ Open Heart, 3(1), 1-10. 
Bán, A. (2015). Telemedicina és földrajz: egy innovatív egészségügyi elltási forma és a földrajzi egyenlötlenségek. [Telemedicine and geography: an innovative form of treatment and the geographical inequalities] Földrajzi Közlemények, 139(4), 318-327.

Bán, A. (2017a). A telemedicina térre és távolságra gyakorolt hatásai és következményei esettanulmány a telekardiológiai szerepéröl. [The effects and consequences of telemedicine on space and distance - A case study about the role of telecardiology.] In T. Cserny, \& B. L. Alpek (Eds.), Bányászat és környezet - harmóniában (pp. 82-85). Pécs: Magyarhoni Földtani Társulat.

Bán, A. (2017b). A telekardiológia és a TTEKG megjelenése és szerepe az alapellátásban háziorvosi interjúk tapasztalatai. [The role of telecardology and TTECG in primary healht care - Interviews with GPs.] Interdiszciplináris Magyar Egészségügy (IME), 16(4), 4144.

Beke, S. (2017). Békés megye népessége az egészségi állapot tükrében. [Population of Békés County in the view of health status] Egészségtudomány, 61(3), 57-74.

Best, L. et al. (2011). Acute Myocardial Infarction Quality of Care: The Strong Heart Study. Ethnicity \& Disease, 21(3), 294-300.

Black D., Morris J. N., Smith, C., \& Townsend, P. (1985). Inequalities in health. The Black Report. Hammondsworth, Middlesex: Penguin Books. 375 p.

Egészségügyi Statisztikai Évkönyv, 2016 [Statistic Annals of Healthcare 2016] [Pdf]. Retrieved from http://www.ksh.hu/docs/hun/xftp/idoszaki/evkonyv/egeszsegugyi_evkonyv_2016.pdf

Egri, Z. (2017). Magyarország városai közötti egészségegyenlötlenségek [Health Inequalities Between Urban Areas in Hungary] Területi Statisztika, 57(5), 537-575.

Ertaş, F. S., \& Tokğg̈zoğlu, L. (2016). Pre- and in-hospital antitrombotic managment patterns and in-hospital outcomes in patients with acute coronary syndrome: data from arm of the EPICOR study. Anatol J. Cardiol, 16, 900-915.

Jánosi, A., \& Offner, P. (2015). A szívinfarktus miatt kezelt betegek ellátásának jellemzői. Nemzeti Szívinfarktus Regiszter [Treatment characteristics of patients with myocardial infarction in Hungary. National Registry] 2013. Cardiologia Hungarica, 45(1), 1-4.

Jones, K., \& Moon, G. (1987). Health, disease and society: A Critical Medical Geography. London-New York: Routledge and Kegan Paul Ltd., Portsmouth Polytechnic, 376 p.

Kaszás, N., Molnár, T., Németh, K., Péter, E., \& Weisz, M. (2012). Healthy Health Care System with Sick People or Healthy People with a Sick Health-Care System? - Resident Satisfaction Survey in Nagykanizsa. Deturope, 04(1), 48-63.

Kiss, É. (2016). Területi különbségek a hazai népesség egészségi állapotában, 1989 után. [Hungarian health inequalities and its regional differences after 1989.] Területi Statisztika, 56 (5), 483-519.

Kiss, R. G., Merkely, B., \& Becker, D. (2014). Az akut iszkémiás szívbetegség korszerü kezelése [Modern Treatment of Acute Ischaemia Heart Disease]. Magyar Tudomány, 175(8), 933-938.

Márk, L., Dani, G., Ruzsa, J., \& Katona, A. (2015). Változott-e a szívinfarktus prehospitális ideje és kezdetének napszaki ingadózása az elmúlt negyedszázadban a gyulai kórház ellátási területén? [Did The prehospital time and circadian variation in the onset of myocardial infarction change in the last two and half decades in the area of Békés County Hospital, Gyula?] Cardiologia Hungarica, 45(4), 253-257.

Maxwell, S. (1999). Emergency management of acute myocardial infarction. British Journal of Clinical Pharmacology, 48(3), 284-98.

MTI (2017). A magyar mentőautók átlag életkora 7 év alá csökkent (sz.n) [Pdf]. Retreived from hvg.hu/itthon/20171119_A_magyar_mentoautok_atlageletkora_7_ev_ala_csokkent

National Ambulance Services' branch office in Békés County database

OECD (2018). Health at a Glance - Europe 2018. State of Health in the EU Cycle. OECD, Paris: OECD Publishing. 
Pál, V. (2017). Egészségünk földrajza - területi különbségek a hazai egészségi állapotban. [Health geography: health inequalities in Hungary.] Magyar Tudomány, 178(3), 311-321.

Porta, M. (2014). A dictionary of epidemiology. Oxford: Oxford University Press.

Rácz, I., Szabó, G., Kolozsvári, R., Fülöp, L., Bódi, A., Péter, A., ...Köszegi, Z. (2010). A falmozgászavar vátozása akut miokardiális infarktusban a tünetektől a revaszkularizációig eltelt idő függvényében [Wall motion changes in myocardial infarction in regards of the time elapsed from symptoms until revascularisation]. Cardiologia Hungarica, 40(2), 104-109.

Uzzoli, A., Vitrai, J., \& Tóth, G. (2017). Az egészségügyi ellátáshoz való hozzáférés területi egyenlőtlenségeinek vizsgálata az akut miokardiális infarktus okozta halálozás adatainak felhasználásával. [The Study of Regional Inequalities Availability of Healthcare Using Mortality Data of Acute Miocardial Heart Attack] Egészségfejlesztés 58(3), 7-17.

Uzzoli, A. (2016). Health inequalities regarding territorial differences in Hungary by discussing life expectancy. Regional Statistics, 6(1), 139-163.

Vitrai, J. (2011). Az egészség és az egészség-egyenlötlenség egyéni és közösségi szintü befolyásoló tényezöi. [Individual and communal influencing factors of health and health inequality.] Doktori értekezés. Pécs: Pécsi Tudományegyetem Egészségtudományi Kar Egészségtudományi Doktori Iskola.

World Health Organization. World Health Statistics 2018. Geneva: WHO. 